\title{
Distribution, Metabolism, and Recovery of Resin Acids in the Intestine and Tissues of Broiler Chickens in a Feeding Trial With Tall Oil Fatty Acid-Supplemented Diets
}

\author{
Juha Apajalahti ${ }^{1 \star}$, Kirsi Vienola ${ }^{1}$, Kari Raatikainen ${ }^{1}$, Hannele Kettunen ${ }^{2}$ and \\ Juhani Vuorenmaa ${ }^{2}$ \\ ${ }^{1}$ Alimetrics Research Ltd, Espoo, Finland, ${ }^{2}$ Hankkija Ltd, Hyvinkää, Finland
}

\section{OPEN ACCESS}

Edited by:

Rajesh Jha,

University of Hawaii at Manoa,

United States

Reviewed by:

Kyung-Woo Lee,

Konkuk University, South Korea

Amit Kumar Singh,

University of Hawaii at Manoa,

United States

${ }^{*}$ Correspondence:

Juha Apajalahti

j.apajalahti@alimetrics.com

Specialty section:

This article was submitted to Animal Nutrition and Metabolism,

a section of the journal

Frontiers in Veterinary Science

Received: 02 March 2020

Accepted: 16 June 2020

Published: 28 July 2020

Citation:

Apajalahti J, Vienola K, Raatikainen K, Kettunen $\mathrm{H}$ and Vuorenmaa J (2020)

Distribution, Metabolism, and Recovery of Resin Acids in the

Intestine and Tissues of Broiler Chickens in a Feeding Trial With Tall Oil Fatty Acid-Supplemented Diets.

Front. Vet. Sci. 7:437.

doi: 10.3389/fvets.2020.00437
Tall oil fatty acids (TOFA) are novel, health-improving feed ingredients which have been shown to improve the performance of broiler chickens. TOFA contains resin acids, the suggested key components for its beneficial effects. For product safety, possible accumulation of TOFA components in tissues consumed by end-users is an issue of major importance. Wheat-soy-based diets with an indigestible marker and TOFA at 0 , 750 and 3,000 g/t were fed to broiler chickens for 5 weeks; 11 replicate pens/treatment. Deposition of resin acids was assessed by analyzing jejunal tissue, breast muscle, abdominal fat, blood, liver, bile, and digesta along the intestinal tract at the end of the 35-day trial. Both free and conjugated resin acids were quantified. With TOFA 3,000 g/t diet, $30 \%$ of ingested resin acids could not be recovered from jejunal digesta. Also, a proportion representing $45 \%$ of resin acids fed were in conjugated form and thus had already re-entered the intestine from the bile duct. This means that at least $75 \%$ of resin acids ingested had become absorbed in, or proximal to jejunum. Recovery of resin acids in excreta was 45 and $70 \%$ when TOFA was fed at 750 and 3,000 g/t, respectively. Based on recovery data, of the estimated $1,087 \mathrm{mg}$ of resin acids ingested by birds on the high TOFA dose during their lifetime, about $330 \mathrm{mg}$ was unaccounted for. In analysis of jejunal tissue, blood, liver, bile, breast muscle, and abdominal tissue, $<1 \mathrm{mg}$ of resin acids was found after the 35-day trial when TOFA at the 4-fold the recommended dose was fed. It is likely that the host or microbiota mineralized or converted one-third of resin acids to a form that escaped analysis. TOFA at 3,000 g/t dose caused no detectable adverse effects in broiler chickens. Based on analysis of breast meat and liver, the common edible tissues, a human consumer would ingest $<100 \mu \mathrm{g}$ of resin acids in a single meal. That is one-thousandth of the dose shown to be harmless in rodents. Thus, unintentional exposure of human consumers to resin acids is marginal, and posed no safety concerns.

Keywords: tall oil fatty acids, resin acids, resin acid conjugates, bacterial deconjugation, broiler chickens 


\section{INTRODUCTION}

The ban on antibiotic growth promoters in an increasing number of countries worldwide has given rise to an intensive search for new products to improve animal performance and health. The most common product categories are organic acids, live-fed microbes (probiotics), oligosaccharides (prebiotics), and many plant-derived products. One new additive used to improve performance and health in production animals is tall oil fatty acids (TOFA), a high-volume side-product from the wood processing industry. It is derived from coniferous trees in the Kraft process, where acylglycerols are hydrolyzed under alkaline conditions into free fatty acids and glycerol, then acidified and eventually distilled to produce the final TOFA product (1).

The raw material for the TOFA used in the present study originated from northern coniferous trees, mainly Scots pine (Pinus sylvestris) and Norway spruce (Picea abies) grown in Finland. Besides long-chain saturated and unsaturated fatty acids ( $\sim 90 \%)$, the product also contained free resin acids $(8.6 \%)$. Resin acids are tricyclic diterpenoids, the most abundant of which in the TOFA product used here were abietic acid, dehydroabietic acid, and palustric acid. Together, these three specific acids accounted for $53.5 \%$ of total resin acids in the product.

The interest in using TOFA and resin acids in animal diets increased substantially when TOFA products were shown to improve body weight gain and feed conversion efficiency in broiler chickens (2-4). The mechanism explaining the positive effects is not known in detail. However, TOFA has been shown to inhibit in vitro growth of some bacteria, especially Clostridium perfringens (4). It is also reported to modulate the immune system of broiler chickens, by suppressing both duodenal inflammatory $\mathrm{T}$ cell infiltration and expression of collagen-degrading matrix metalloproteinases $(5,6)$. During the past year, the role of different TOFA compounds has been intensively studied. The results suggest that resin acids may be the most important group of compounds mediating positive effects of TOFA on animal performance (7).

Whatever the underlying mechanism for the beneficial growth effects in broiler chickens, it is important for product safety to know whether any components of TOFA products accumulate in tissues consumed by end-users. While the fate and metabolism of long-chain fatty acids in animals have been extensively studied $(8,9)$, the fate of ingested resin acids is poorly understood. There are no prior reports showing the detailed effects of resin acids in monogastric production animals in tissue level. However, their metabolism in fish has been studied in research investigating how the discharge of resin acid-containing wastewaters from wood processing affects fish living in recipient waterways $(10,11)$. In those studies, resin acids have been in water-soluble form and the entry to fish is assumed to be primarily through gills. With rodents, only toxicity studies with resin acids have been reported. Although rats are different from poultry and pigs, at least the exposure to resin acids comes through the same oral route. These studies suggest that rodents can tolerate relatively high doses of resin acids (12-14).

In the present study, the main objective was to investigate the distribution of resin acids in the digestive tract and tissues of broiler chickens when a commercial TOFA product was added in the diet at the recommended and 4-fold the recommended dose. Using an indigestible marker compound in the diet, the proportion of in-feed resin acids excreted with feces was also assessed. With the experimental arrangement used it was also possible to analyze the extent to which accumulation of resin acids in tissues took place during the 5-week trial.

\section{MATERIALS AND METHODS}

\section{Animals and Housing}

A 35-day feeding trial with broiler chickens, in accordance with EU Directive 2010/63/EU, was conducted at the research facility of Alimetrics Ltd in Southern Finland. The trial was started in January 2018. Newly hatched chicks were obtained from a commercial hatchery (DanHatch, Mynämäki, Finland) and were not given vaccinations or commercial inoculants. In the trial, 15 male broilers of breed Ross 308 (Aviagen) were allocated in each floor pen. There were 3 dietary treatments each fed to 11 replicate pens; in total 33 pens and 495 birds.

The temperature of the house was raised to $32^{\circ} \mathrm{C} 2$ days before the chicks arrived. One-day-old chicks were randomly allocated to 33 open floor pens of $1.125 \mathrm{~m}^{2}$, bedded with wood shavings litter. Luminosity was adjusted to 20 lux and air humidity to $60 \%$. Brooder lamps were adjusted to provide extra heating during the first week, and the temperature was gradually decreased to $22^{\circ} \mathrm{C}$ during the first 2 weeks of the trial. Temperature, ventilation, and humidity were monitored continuously throughout the trial. From day 1 , the hours of darkness were increased daily by $1 \mathrm{~h}$ from $24 \mathrm{~h}$ light until the light-dark cycle was $18 \mathrm{~h}$ light and $6 \mathrm{~h}$ darkness daily. Feed and water were freely available at all times. The weight of birds and feed consumption per pen were measured on days $0,14,21$, and 35 . Dead birds and birds euthanized because of health problems were weighed and daily mortality was recorded.

\section{Dietary Treatments}

The basal starter and grower diets were wheat-soy based pelleted feeds, the composition of which are shown in Table 1. Two-phase feeding was used: the starter diet was fed on days $0-14$ and the grower diet on days 14-35. The starter diets were prepared as $2 \mathrm{~mm}$ crushed pellets and the grower diets as $4 \mathrm{~mm}$ pellets. The dietary treatments employed in each trial and the results of diet analysis are shown in Table 2. In addition to the control, treatments with TOFA at two doses were used. The TOFA was mixed with sunflower oil before inclusion in the treatments and it replaced a corresponding amount of sunflower oil in the diet. The test TOFA product used was a commercial product (Progres ${ }^{\mathrm{TM}}$ ) obtained from Hankkija Ltd (Hyvinkää, Finland) and produced at the tall oil refinery of Forchem Ltd (Rauma, Finland). The test TOFA product contained about $90 \%$ free fatty acids (of which 50 $55 \%$ various linoleic acids, $25-30 \%$ oleic acid, and $6-8 \%$ pinolenic acid) and $8.6 \%$ resin acids. Titanium dioxide $\left(\mathrm{TiO}_{2}\right)$ was added to all diets at $3 \mathrm{~kg} / \mathrm{t}$ as a digestibility marker. All feeds were manufactured by Alimetrics Ltd, Finland.

The feeds were subjected to proximate analysis, and analysis of $\mathrm{TiO}_{2}$ and major resin acids. The results indicated that nutritional 
values were close to the target and nearly identical in different starter and grower diets (Table 2). The target $\mathrm{TiO}_{2}$ dose was 3 $\mathrm{kg} / \mathrm{t}$. The analyzed values in starter diets ranged between 2.82 and

TABLE 1 | Components of basic diets used in the trial.

\begin{tabular}{lcc}
\hline Added ingredients $\mathbf{( g / k g )}$ & Starter diet & Grower diet \\
\hline Wheat & 571.5 & 675.1 \\
Soybean meal & 340.0 & 253.0 \\
Sunflower oil & 41.0 & 3.2 \\
Monocalcium phosphate & 16.5 & 15.2 \\
Limestone & 16.7 & 12.5 \\
Sodium chloride & 4.1 & 3.9 \\
Mineral premix & 2.0 & 2.0 \\
Vitamin premix & 2.0 & 2.0 \\
DL-methionine & 2.7 & 2.2 \\
L-lysine & 2.5 & 2.1 \\
Threonine & 1.0 & 0.0 \\
\hline Calculated nutrient concentrations & Starter diet & Grower diet \\
\hline Metabolizable energy (MJ/kg) & 12.30 & 12.51 \\
Crude protein & 231.29 & 201.81 \\
Lysine & 13.38 & 10.98 \\
Methionine & 5.97 & 5.11 \\
Threonine & 9.37 & 7.13 \\
Methionine + cysteine & 9.54 & 8.42 \\
Calcium & 10.35 & 8.32 \\
Non-phytate phosphorus & 4.27 & 3.94 \\
\hline
\end{tabular}

${ }^{a}$ composition: calcium $296.9 \mathrm{~g} / \mathrm{kg}$, zinc $32.5 \mathrm{~g} / \mathrm{kg}$, manganese $25.0 \mathrm{~g} / \mathrm{kg}$, iron $12.5 \mathrm{~g} / \mathrm{kg}$, copper $4.0 \mathrm{~g} / \mathrm{kg}$, iodine $225 \mathrm{mg} / \mathrm{kg}$, selenium $100 \mathrm{mg} / \mathrm{kg}$.

${ }^{b}$ composition: calcium $331.3 \mathrm{~g} / \mathrm{kg}$, all-rac- $\alpha$-tocopheryl acetate $30.0 \mathrm{~g} / \mathrm{kg}$, niacin 20.1 $\mathrm{g} / \mathrm{kg}$, panthotenic acid $7.51 \mathrm{~g} / \mathrm{kg}$, riboflavin $3.0 \mathrm{~g} / \mathrm{kg}$, pyridoxine $2.01 \mathrm{~g} / \mathrm{kg}$, retinol 1.8 $\mathrm{g} / \mathrm{kg}$, menadione $1,505 \mathrm{mg} / \mathrm{kg}$, thiamine $1,257 \mathrm{mg} / \mathrm{kg}$, folic acid $504 \mathrm{mg} / \mathrm{kg}$, biotin 75.0 $\mathrm{mg} / \mathrm{kg}$, cholecalciferol $56.3 \mathrm{mg} / \mathrm{kg}$, cobalamin $12.5 \mathrm{mg} / \mathrm{kg}$.
$2.90 \mathrm{~kg} / \mathrm{t}$ and those in grower diets between 3.08 and $3.23 \mathrm{~kg} / \mathrm{t}$. Resin acid analysis concentrated on three major individual acids (abietic, dehydroabietic, and palustric). The analysis showed that the combined concentration of the three acids were 52.0 and 53.4 $\mathrm{g} / \mathrm{t}$, respectively, for the starter and grower diet supplemented with $750 \mathrm{~g} / \mathrm{t}$ TOFA, and 168 and $166 \mathrm{~g} / \mathrm{t}$, respectively, for the starter and grower diet supplemented with 3,000 g/t TOFA. According to the TOFA manufacturer's specification, the three acids analyzed represented $53.5 \%$ of total resin acids in the product. Based on this information, the total resin acid content of the diets was calculated to be $\sim 98$ and $312 \mathrm{~g} / \mathrm{t}$ for the diets supplemented with 750 and 3,000 g/t TOFA, respectively (Table 2). The figures obtained from such arithmetic procedure in this paper are referred to as "total calculated resin acids" and it is based on the assumption that all resin acids in TOFA act in live animal similar to the dominating ones abietic and dehydroabietic acid.

\section{Sampling}

On day 34 of the trial, a piece of plastic film was spread out in each pen on the litter material for excreta collection. After $3 \mathrm{~h}$, the plastic films were removed and excreta from each pen were carefully transferred to a glass jar and frozen until analysis. On day 35, two birds from each pen were euthanized by cervical dislocation. The abdominal cavity was opened, the small intestine removed, and digesta from jejunum and ileum snap-frozen in dry ice and stored frozen until analysis of resin acids and $\mathrm{TiO}_{2}$. In addition, samples of jejunal tissue, breast muscle tissue, abdominal fat, blood, liver, and bile were taken from the birds on the control diet and birds on the diet with the higher dose of TOFA, and analyzed for resin acids. Blood samples were taken with cardiac puncture immediately after euthanasia, mixed with heparin, and centrifuged at $1,500 \times \mathrm{g}$ for $10 \mathrm{~min}$ for plasma preparation. The rationale for selecting specific sample types for analysis was to get information firstly on resin acid conjugation

TABLE 2 | Analyzed composition of the starter and grower diets fed to broiler chickens.

\begin{tabular}{|c|c|c|c|c|c|c|c|}
\hline Concentration/feed DM & \multicolumn{3}{|c|}{ Starter diets } & \multicolumn{3}{|c|}{ Grower diets } & SE \\
\hline $\mathrm{TiO}_{2}, \mathrm{~kg} / \mathrm{t}$ & 2.82 & 2.90 & 2.83 & 3.23 & 3.08 & 3.18 & 0.11 \\
\hline$A A, g / t$ & 0.0 & 31.6 & 101 & 0.0 & 32.2 & 100 & 0.79 \\
\hline $\mathrm{DHA}, \mathrm{g} / \mathrm{t}$ & 0.0 & 14.1 & 47.6 & 0.0 & 15.0 & 47.4 & 0.68 \\
\hline Calc. total RA, $g / t^{a}$ & 0.0 & 97.2 & 314 & 0.0 & 99.8 & 310 & 3.01 \\
\hline Crude protein, $\mathrm{kg} / \mathrm{t}^{\mathrm{b}}$ & 249 & 251 & 258 & 219 & 202 & 211 & - \\
\hline Crude fat, $\mathrm{kg} / \mathrm{t}^{\mathrm{b}}$ & 65 & 69 & 69 & 61 & 60 & 59 & - \\
\hline Crude fiber, $\mathrm{kg} / \mathrm{t}^{\mathrm{b}}$ & 20 & 19 & 18 & 20 & 21 & 19 & - \\
\hline Ash, $\mathrm{kg} / \mathrm{t}^{\mathrm{b}}$ & 76 & 79 & 79 & 71 & 70 & 70 & - \\
\hline
\end{tabular}

TOFA, tall oil fatty acids; AA, abietic acid; DHA, dehydroabietic acid; PA, palustric acid; RA, resin acids; SE, standard error.

${ }^{a}$ calculation based on the percentage of $A A+D H A+P A$ in total resin acids in TOFA (53.5\%), as reported by the manufacturer.

${ }^{b}$ proximate analysis outsourced to Eurofins. 
and passage through enterohepatic circulation and secondly on resin acid concentration in some common edible tissues. Fecal sampling took place 1 day before the animals were sacrificed since it was not possible to collect feces and sacrifice animals for tissue sampling at the same time without compromising both sampling procedures. All tissue samples were frozen immediately and stored at $-20^{\circ} \mathrm{C}$ until analysis.

\section{Analysis Methods Resin Acids}

General procedure for analysis of all sample matrices

Samples were thawed and thoroughly homogenized. For analysis of total (free + conjugated) resin acid content, representative samples were weighed and mixed with 1.5-6.0M $\mathrm{KOH}$ (depending on the tissue type; see details below), followed by incubation in a water bath at $75^{\circ} \mathrm{C}$ for $2 \mathrm{~h}$. A previously published alkaline hydrolysis procedure was used to liberate resin acids from glucuronide and sulfate conjugates $(15,16)$. After hydrolysis, the samples were cooled in ice-water and neutralized to $\mathrm{pH} 7-8$ with $3 \mathrm{M} \mathrm{H}_{3} \mathrm{PO}_{4}$. In the analysis of free resin acids, the samples were not hydrolyzed but mixed with a $\mathrm{pH}$-neutral mixture of $\mathrm{KOH}$ and $\mathrm{H}_{3} \mathrm{PO}_{4}$, resulting in a mixture with equal ion strength as the samples analyzed for total resin acids.

Resin acids were then extracted for 30 min with a 1:4 mixture of methanol and ethyl acetate containing nonadecanoic acid as an internal standard. After centrifugation, the organic phase was collected and a defined subsample of that evaporated to dryness (see exact volumes for each sample type below). The residue was then dissolved in a solution with 1 volume of N,O-bistrimethylsilyl-trifluoroacetamide with $1 \%$ trimethylchlorosilane and 1 volume of pyridine. The analyte was derivatized to the respective trimethylsilyl ester by heating the sample at $60^{\circ} \mathrm{C}$ for $30 \mathrm{~min}$. Matrix-matched standards were used in calibration. An Agilent 7890A gas chromatograph equipped with 5975C mass detector was used in the analyses. The column was HP-5MS (60 m $\times 250 \mu \mathrm{m} \times 0.25 \mu \mathrm{m})$ and data were collected with single ion mode. Feed samples were analyzed and quantified for abietic, dehydroabietic, and palustric acid. It turned out to be difficult to quantify palustric acid in tissues since its proportion of total resin acids was low as compared to abietic and dehydroabietic acid, and, in the difficult sample matrices no baseline separation was achieved. Therefore, we report only abietic and dehydroabietic acid concentrations in samples of animal origin.

\section{Analysis of feed, digesta, and liver samples}

A representative $1.5 \mathrm{~g}$ sample was hydrolyzed with $2 \mathrm{~mL}$ of $1.5 \mathrm{M}$ $\mathrm{KOH}$ and neutralized with $0.5 \mathrm{~mL}$ of $3 \mathrm{M} \mathrm{H}_{3} \mathrm{PO}_{4}$. Ten milliliter of organic extraction solution was used, of which $0.5 \mathrm{~mL}$ was collected, evaporated to dryness and derivatized with $150 \mu \mathrm{L}$ of the silylation reagent.

\section{Analysis of meat samples}

A representative $5.0 \mathrm{~g}$ sample was hydrolyzed with $3 \mathrm{~mL}$ of $3 \mathrm{M}$ $\mathrm{KOH}$ and neutralized with $1.5 \mathrm{~mL}$ of $3 \mathrm{M} \mathrm{H}_{3} \mathrm{PO}_{4}$. In this case, $25 \mathrm{~mL}$ of organic extraction solution was used, of which $1.0 \mathrm{~mL}$ was collected, evaporated to dryness and derivatized with $200 \mu \mathrm{L}$ of the silylation reagent.

\section{Analysis of adipose tissue samples}

A representative $0.5 \mathrm{~g}$ sample was hydrolyzed with $1 \mathrm{~mL}$ of $3 \mathrm{M}$ $\mathrm{KOH}$ and neutralized with $0.5 \mathrm{~mL}$ of $3 \mathrm{M} \mathrm{H}_{3} \mathrm{PO}_{4}$. Ten milliliter of organic extraction solution was used, of which $0.5 \mathrm{~mL}$ was collected, evaporated to dryness and derivatized with $150 \mu \mathrm{L}$ of the silylation reagent.

\section{Analysis of jejunal tissue samples}

A representative $0.5 \mathrm{~g}$ sample was hydrolyzed with $0.4 \mathrm{~mL}$ of $6 \mathrm{M}$ $\mathrm{KOH}$ and neutralized with $0.4 \mathrm{~mL}$ of $3 \mathrm{M} \mathrm{H}_{3} \mathrm{PO}_{4}$. In this case, $4.4 \mathrm{~mL}$ of organic extraction solution was used, of which $2.5 \mathrm{~mL}$ was collected, evaporated to dryness and derivatized with $200 \mu \mathrm{L}$ of the silylation reagent.

\section{Analysis of blood plasma samples}

A $0.4 \mathrm{~mL}$ sample was hydrolyzed with $0.1 \mathrm{~mL}$ of $6 \mathrm{M} \mathrm{KOH}$ and neutralized with $0.1 \mathrm{~mL}$ of $3 \mathrm{M} \mathrm{H}_{3} \mathrm{PO}_{4}$. One milliliter of organic extraction solution was used, of which $0.5 \mathrm{~mL}$ was collected, evaporated to dryness and derivatized with $150 \mu \mathrm{L}$ of the silylation reagent.

\section{Analysis of bile samples}

A $0.2 \mathrm{~mL}$ sample was hydrolyzed with $0.1 \mathrm{~mL}$ of $6 \mathrm{M} \mathrm{KOH}$ and neutralized with $0.1 \mathrm{~mL}$ of $3 \mathrm{M} \mathrm{H}_{3} \mathrm{PO}_{4}$. One milliliter of organic extraction solution was used, of which $0.5 \mathrm{~mL}$ was collected, evaporated to dryness and derivatized with $150 \mu \mathrm{L}$ of the silylation reagent.

\section{$\mathrm{TiO}_{2}$}

The method used for the analysis of $\mathrm{TiO}_{2}$ in feed, digesta, and excreta followed a previously published protocol (17). The method involves sample combustion in a furnace, titanium (Ti) dissolution in hot sulfuric acid $\left(\mathrm{H}_{2} \mathrm{SO}_{4}\right)$, and finally reaction with hydrogen peroxide $\left(\mathrm{H}_{2} \mathrm{O}_{2}\right)$. The intensely colored Ti- $\mathrm{H}_{2} \mathrm{O}_{2}$ complex was measured quantitatively with UV/VIS spectroscopy.

\section{Dry Matter Content}

For dry matter determination, samples were weighed, dried at $105^{\circ} \mathrm{C}$ for $12 \mathrm{~h}$, and weighed again.

\section{Statistical Analysis}

The data were first subjected to one-way ANOVA using the IBM SPSS Statistics Subscription (Build 1.0.0.1327). ANOVA $P$-values lower than 0.05 were considered significant. The data were then subjected to either Tukey's test or Students' $t$-test, as specified in the legend of each table and figure.

\section{RESULTS}

\section{Effect of Tall Oil Fatty Acids on Performance of Broiler Chickens}

The broiler chicken groups were fed the control diet or a diet supplemented with TOFA at 750 or $3,000 \mathrm{~g} / \mathrm{t}$ for 5 weeks. In this trial, none of the treatments had any effect on performance parameters (Table 3). 
TABLE 3 | Effect of diets containing tall oil fatty acids on performance of broiler chickens.

\begin{tabular}{|c|c|c|c|c|c|}
\hline Parameter & Control & $\begin{array}{c}\text { TOFA } 750 \\
\text { g/t }\end{array}$ & $\begin{array}{c}\text { TOFA } \\
3,000 \\
\mathrm{~g} / \mathrm{t}\end{array}$ & $\mathrm{SE}^{\mathrm{a}}$ & $P$-value ${ }^{\mathrm{b}}$ \\
\hline \multicolumn{6}{|l|}{ Day 0-14 } \\
\hline Initial BW (g) & 38.9 & 38.6 & 38.8 & 0.19 & 0.450 \\
\hline BWG (g) & 507 & 495 & 506 & 7.12 & 0.424 \\
\hline FC (kg/pen) & 8.7 & 8.5 & 8.7 & 0.11 & 0.525 \\
\hline FCR & 1.16 & 1.16 & 1.18 & 0.01 & 0.331 \\
\hline Mortality (\%) & 1.8 & 1.2 & 3.0 & 0.93 & 0.390 \\
\hline Mortality-corrected FCR & 1.15 & 1.15 & 1.16 & 0.00 & 0.334 \\
\hline \multicolumn{6}{|l|}{ Day 0-21 } \\
\hline BWG (g) & 1,023 & 1,003 & 1,019 & 14.15 & 0.587 \\
\hline FC (kg/pen) & 20.4 & 20.0 & 20.3 & 0.29 & 0.598 \\
\hline FCR & 1.36 & 1.37 & 1.38 & 0.01 & 0.429 \\
\hline Mortality (\%) & 1.8 & 2.7 & 3.0 & 1.20 & 0.526 \\
\hline Mortality-corrected FCR & 1.35 & 1.36 & 1.37 & 0.01 & 0.358 \\
\hline \multicolumn{6}{|l|}{ Day 0-35 } \\
\hline BWG (g) & 2,694 & 2,637 & 2,666 & 33.74 & 0.504 \\
\hline FC (kg/pen) & 59.9 & 59.1 & 59.8 & 1.15 & 0.882 \\
\hline FCR & 1.60 & 1.55 & 1.58 & 0.02 & 0.349 \\
\hline Mortality (\%) & 6.1 & 3.0 & 4.2 & 1.67 & 0.468 \\
\hline Mortality-corrected FCR & 1.54 & 1.54 & 1.55 & 0.01 & 0.270 \\
\hline
\end{tabular}

TOFA, tall oil fatty acids; BW, body weight; BWG, body weight gain; FC, feed consumption; FCR, feed conversion ratio.

${ }^{a}$ pooled standard error. ${ }^{b} \mathrm{P}$-value from ANOVA.

\section{Passage of Resin Acids Through the Intestinal Tract}

The concentration of resin acids was analyzed in jejunal digesta, ileal digesta, and excreta of 5-week-old broiler chickens. The results showed that the residual concentration of both abietic acid and dehydroabietic acid increased with the increasing rate of TOFA inclusion in the diet (Figure 1). In both jejunum and ileum, the concentration of abietic acid was about twice the concentration of dehydroabietic acid, i.e., close to their respective relative proportions in the diet. In the ileum, the concentrations of both acids were somewhat higher than in jejunum. Assessment of the recovery of in-feed resin acids in samples, using $\mathrm{TiO}_{2}$ as an indigestible marker compound, showed that in jejunum, about $50 \%$ of dietary abietic and dehydroabietic acids were present in digesta when the dose of TOFA in the diet was $750 \mathrm{~g} / \mathrm{t}$. When the dietary TOFA inclusion rate was higher, 3,000 g/t, up to $70 \%$ of the two main resin acids were recovered in jejunal digesta (Figure 1A2). In the ileum, the effect of TOFA dose on resin acid recovery was less significant, with the recovery rate ranging from 50 to $60 \%$ of abietic and dehydroabietic acid added in the diet (Figure 1B2). Based on the analysis of excreta samples for the main resin acids, it was concluded that the higher the dose of resin acids in the diet, the higher the percentage excreted. When the dose of TOFA in the diet was 3,000 g/t, close to $70 \%$ of total abietic and dehydroabietic acids was excreted. When the TOFA dose in the diet was $750 \mathrm{~g} / \mathrm{t}$, about $45 \%$ of the two resin acids fed was excreted (Figure 1C2).

\section{Degree of Conjugation of Resin Acids in the Digestive Tract}

In order to assess the degree of conjugation, resin acids in digesta were analyzed before and after hydrolytic deconjugation. In digesta sampled from jejunum and ileum, on average $65 \%$ of abietic and dehydroabietic acids found were in a conjugated form (Figures 1A,B). In excreta the proportion of conjugated resin acids was lower, representing only $10-20 \%$ of total abietic and dehydroabietic acids (Figure 1C).

The results also revealed a difference in the degree of conjugation of abietic acid and dehydroabietic acid. Analysis of samples representing different parts of the digestive tract showed that abietic acid was consistently conjugated to a higher degree than dehydroabietic acid. The difference between the two acids was statistically most significant in ileum (Figure 2). Numerically, the difference in the degree of conjugation was greatest in excreta, where the proportion of the conjugated form of dehydroabietic acid was less than half that of the conjugated form of abietic acid.

\section{Free and Conjugated Resin Acids in Liver and Bile}

Also in liver and bile samples, both free and total resin acids were analyzed. Overall, the concentration of abietic and dehydroabietic acids in liver tissue was low compared with their concentration in intestinal digesta. In birds on the 3,000 g/t TOFA diet, the concentration of the dominant resin acid, abietic acid, in the liver was below $0.3 \mathrm{mg} / \mathrm{kg}$ (Table 4). Furthermore, resin acids were found only after deconjugation, indicating that they were all in conjugated form. The concentration of dehydroabietic acid was less than half that of abietic acid, and thus the relative proportions of the two acids were approximately the same as in the TOFA-supplemented feeds.

In bile, the concentration of resin acids was 150-fold higher than in liver tissue, with the total concentration reaching nearly $70 \mathrm{mg} / \mathrm{kg}$. The ratio of dehydroabietic to abietic acid appeared to be somewhat elevated in bile compared with that in liver tissue in birds fed the TOFA-supplemented feeds. Interestingly, some free resin acids were found in bile in birds that were on the control diet. However, nearly 20-fold higher concentration was seen in birds fed the 3,000 g/t TOFA diet (Table 4). In the birds from this dietary group, around $80 \%$ of abietic and dehydroabietic acids in bile were in conjugated form.

\section{Residues of Resin Acids in Other Tissues}

Since resin acids are poorly water-soluble, it was of interest to measure their concentration also in intestinal tissue. Jejunal tissue of the TOFA-fed birds indeed had measurable amounts of resin acids, with the sum concentration of abietic and dehydroabietic acids exceeding $3 \mathrm{mg} / \mathrm{kg}$ (Table 5). The concentration of resin acids in jejunal tissue of the control birds was below detection.

The total resin acid concentration in blood plasma was only one-tenth of that found in jejunal tissue. In adipose tissue, the concentration of resin acids was below detection, while the mean 


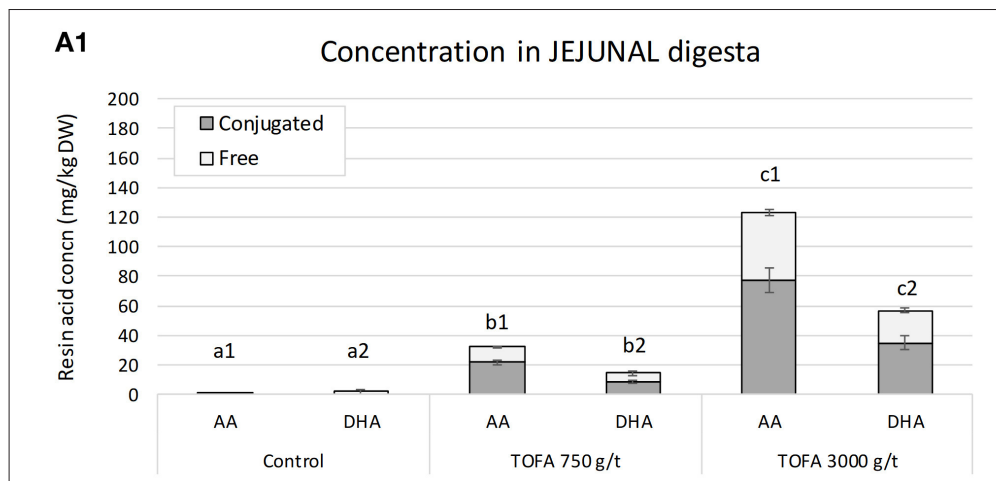

B1

Concentration in ILEAL digesta

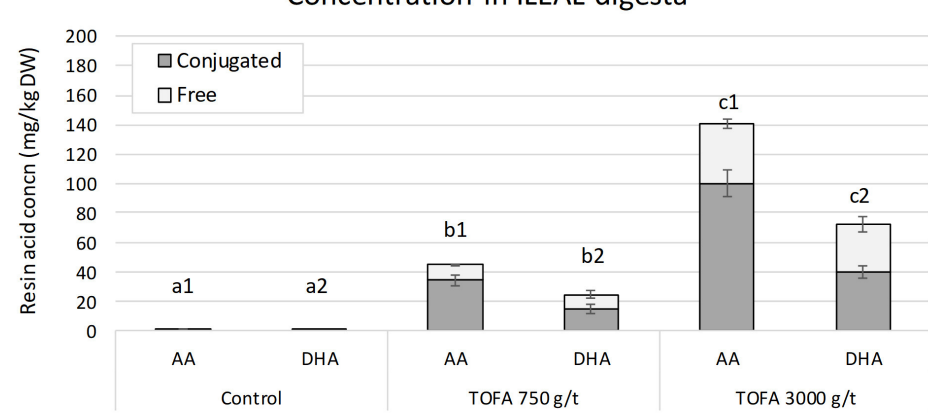

C1

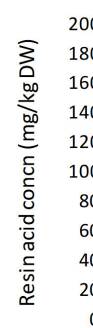

\section{Concentration in EXCRETA}

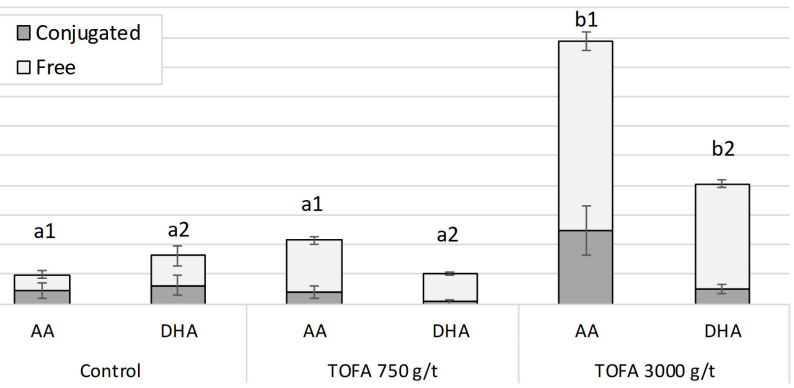

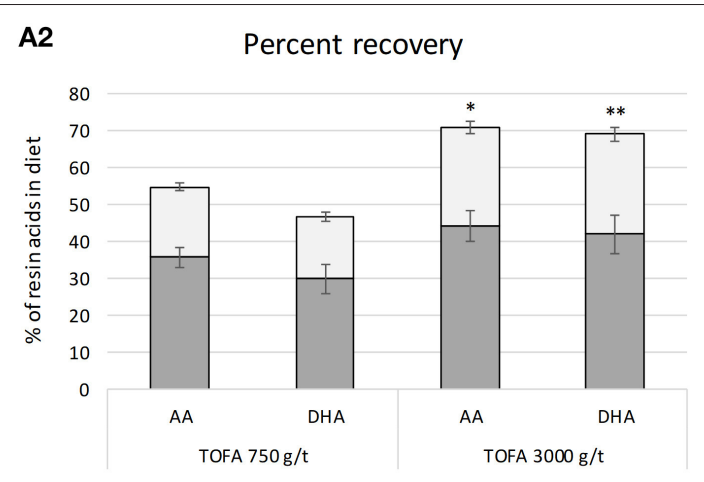
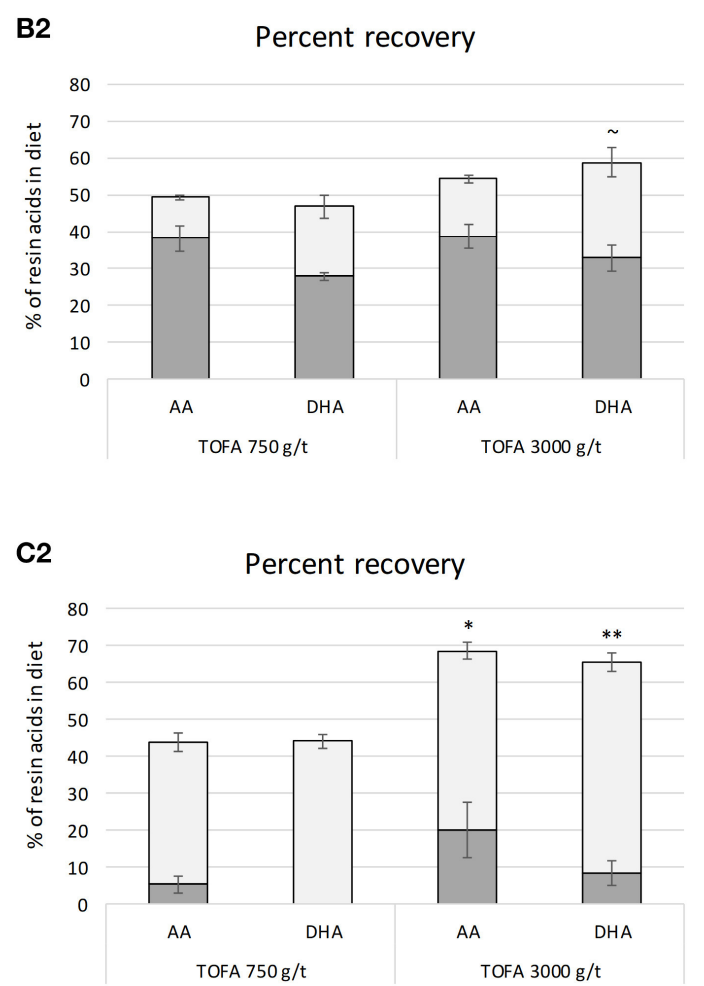

B2

C2

FIGURE 1 | Residual concentration and percent recovery of resin acids in intestinal digesta on day 34. (A1-C1) Show the residual concentration, and (A2-C2) the percent recovery of resin acids in jejunal digesta, ileal digesta, and excreta, respectively. Total height of bars shows the total abietic (AA) and dehydroabietic (DHA) acid concentration, while the color indicates the proportion of free and conjugated forms. The error bars show standard error of the mean. (A1-C1) Different superscripts above the bars for AA (a1-c1) and DHA (a2-c2) indicate significant differences between diets by Tukey HSD test $(P<0.05)$. Recovery indicates proportion of residua resin acids of the amount added in the diet and it was calculated using $\mathrm{TiO}_{2}$ as a digestibility marker. (A2-C2) Asterisks indicate significance of difference in $\mathrm{AA}$ and DHA recovery between the two TOFA-supplemented diets $\left(\sim P<0.1 ;{ }^{\star} P<0.05\right.$; $\left.{ }^{\star \star} P<0.01\right)$.

concentration in breast meat was $0.026 \mathrm{mg} / \mathrm{kg}$. However, due to variability in analytical results that were at or just above the detection limit, the concentration of resin acids did not differ significantly between birds in the control group and birds in the group fed 3,000 g/t TOFA for 5 weeks (Table 5).

\section{DISCUSSION}

During the past few decades, the potential of various plantderived extracts and process byproducts has been tested as feed additives for production animals. TOFA products are a recent example of a feed additive, with several studies demonstrating that TOFA improves the performance of broiler chickens (24). More recently, pure resin acids in TOFA have been found to improve performance in the absence of the long-chain fatty acids and other compounds in the raw TOFA byproduct (7). It appears that resin acids play a key role in the positive effects of TOFA, with recent studies showing that pure resin acids decrease collagen-degrading activity in the intestinal tissue (5). Such findings prompted the present investigation on the fate of 

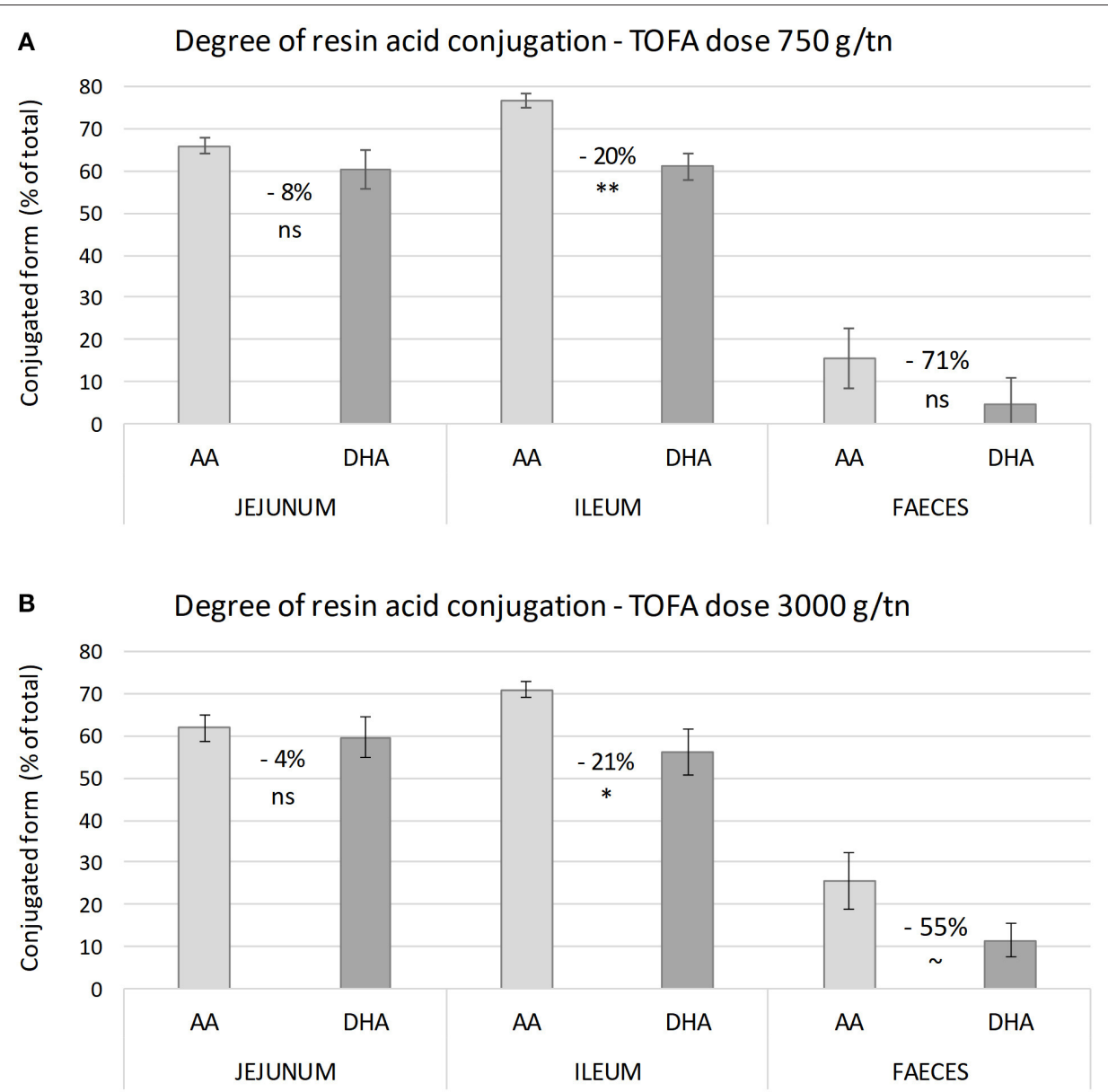

FIGURE 2 | Degree of conjugation of abietic and dehydroabietic acid in intestinal digesta on day 34. (A,B) Show the proportion of conjugated resin acids in digesta from different parts of broiler chicken intestine with a tall oil fatty acid inclusion rate in the diet of 750 and 3,000 g/t, respectively. Values between bars indicate percent difference in degree of conjugation between abietic (AA) and dehydroabietic acid (DHA). The error bars show standard error of the mean. Asterisks indicate significance of difference in degree of conjugation (ns, non-significant; $\sim P<0.1 ;{ }^{*} P<0.05 ;{ }^{* \star} P<0.01$ ).

TABLE 4 | Concentration of free and conjugated resin acids in liver and bile ( $\mathrm{mg} / \mathrm{kg}$ fresh weight) of broiler chickens fed a tall oil fatty acid containing diet for 35 days.

\begin{tabular}{|c|c|c|c|c|c|c|c|c|c|}
\hline & $\begin{array}{l}\text { Form of resin } \\
\text { acid in tissue }\end{array}$ & \multicolumn{2}{|c|}{ Control diet } & \multicolumn{2}{|c|}{ TOFA $3,000 \mathrm{~g} / \mathrm{t}$} & \multicolumn{2}{|c|}{$\mathrm{SE}^{\mathrm{a}}$} & \multicolumn{2}{|c|}{$P$-value ${ }^{b}$} \\
\hline & Conjugated & 0.00 & 0.00 & 0.27 & 0.11 & 0.01 & 0.01 & 0.0000 & 0.0000 \\
\hline & Total & 0.00 & 0.00 & 0.27 & 0.11 & 0.01 & 0.01 & 0.0000 & 0.0000 \\
\hline \multirow[t]{2}{*}{ Bile } & Free & 2.26 & 1.24 & 8.41 & 5.14 & 0.83 & 0.46 & 0.0005 & 0.0002 \\
\hline & Total & 2.26 & 1.24 & 43.7 & 25.2 & 3.45 & 1.81 & 0.0001 & 0.0000 \\
\hline
\end{tabular}

TOFA, tall oil fatty acids; AA, abietic acid; DHA, dehydroabietic acid.

${ }^{a}$ standard error of the mean. ${ }^{b} P$-value calculated with students' $t$-test.

resin acids, which are presumed to be enduring, in the intestinal tract and tissues of broiler chickens. From a consumer safety and regulatory perspective, it would be preferable if resin acids did not accumulate in edible tissues such as breast meat and liver to any significant extent, but rather become metabolized or eliminated with excreta.

In the present study, a TOFA product containing $8.6 \%$ resin acids was added to broiler chicken diets in doses 750 and 3,000 
TABLE 5 | Residues ( $\mathrm{mg} / \mathrm{kg}$ fresh weight) of total resin acids in different tissues from broiler chickens fed a tall oil fatty acid containing diet for 35 days.

\begin{tabular}{|c|c|c|c|c|c|c|c|c|}
\hline & \multicolumn{2}{|c|}{ Control diet } & \multicolumn{2}{|c|}{ TOFA $3,000 \mathrm{~g} / \mathrm{t}$} & \multicolumn{2}{|c|}{$\mathrm{SE}^{\mathrm{a}}$} & \multicolumn{2}{|c|}{$P$-value ${ }^{b}$} \\
\hline & $\mathbf{A A}$ & DHA & AA & DHA & AA & DHA & AA & DHA \\
\hline Jejunal tissue & 0.000 & 0.000 & 2.132 & 1.133 & 0.104 & 0.057 & 0.0002 & 0.0002 \\
\hline Blood plasma & 0.000 & 0.000 & 0.311 & 0.050 & 0.024 & 0.005 & 0.0014 & 0.0052 \\
\hline Adipose tissue & 0.000 & 0.000 & 0.000 & 0.000 & 0.000 & 0.000 & - & - \\
\hline Breast meat & 0.000 & 0.000 & 0.021 & 0.005 & 0.007 & 0.002 & 0.1747 & 0.2261 \\
\hline
\end{tabular}

TOFA, tall oil fatty acids; $A A$, abietic acid; DHA, dehydroabietic acid; resin acid concentrations represent total acids after deconjugation.

${ }^{a}$ standard error of the mean. ${ }^{b} \mathrm{P}$-value calculated with students' $t$-test.

$\mathrm{g} / \mathrm{t}$, and birds were fed the diets for 5 weeks. No performance effects were detected, which can at least partly be explained by the high performance in all treatment groups; all groups exceeded the growth performance recommendations of Aviagen for the Ross 308 breed. The total calculated resin acids ingested by an average single bird during the 35-day trial was 272 and $1,087 \mathrm{mg}$ with the 750 and 3,000 g/t dose, respectively. During the last days of the trial, the proportion of in-feed abietic and dehydroabietic acids recovered from feces was $\sim 44$ and $67 \%$ for diets supplemented with 750 and 3,000 g/t TOFA, respectively. Indeed, the proportion of resin acids that could not be recovered was greater when the dose in the feed was lower, suggesting that the rate of resin acid metabolism or deposition in tissues is ratelimited, not linearly concentration-dependent. There are no prior studies on the fate of resin acids in chickens. In feeding studies with rats given a single oral dose of 2 or $300 \mathrm{mg}$ of tritiumlabeled dehydroabietic acid, it was found that $80-90 \%$ of the radioactivity was excreted with feces within 2 days (reviewed in 14). In the same study, $5-7 \%$ of tritium label administered with dehydroabietic acid was recovered in the urine. In broiler chickens, urine enters the cloaca and is eventually excreted together with feces. Thus, any resin acids secreted from the kidney with urine would have been included in the excreta analysis in this study. Interestingly, our results showed that, at the higher dose of TOFA, the average recovery of abietic and dehydroabietic acids in excreta was $10 \%$ higher than recovery in the ileum. This could be explained by the release of urine in the cloaca, distal to the ileum.

When the dose of TOFA in feed was $3,000 \mathrm{~g} / \mathrm{t}$, the fate of about $30 \%$ of abietic and dehydroabietic acids fed was unknown. If the same proportion also of other ingested resin acids remained unrecovered, about $330 \mathrm{mg}$ of resin acids would be unaccounted for during the 35-day lifetime of an average bird. In the study described here, intestinal tissue, blood, liver, bile, breast meat and abdominal fat were analyzed for resin acids. Based on the results, we estimated that no more than $1 \mathrm{mg} / \mathrm{bird}$ was deposited as resin acids in these tissues after the 35-day trial, when TOFA at the 4fold the recommended dose was fed. Thus, it is likely that the majority of the unrecovered fraction of resin acids was in fact excreted with feces but, prior to that, had been metabolized and was no longer in the original analyzable form.

The results showed that already in the jejunum, only 50$70 \%$ of the ingested abietic and dehydroabietic acids could be found. This suggests that resin acid uptake by the bird was highly active already in the upper gastrointestinal tract. Absorption of poorly water-soluble acidic compounds can be expected to occur in the crop and, especially, the proventriculus-gizzard with low prevailing $\mathrm{pH}$. We detected relatively high concentrations of resin acids in jejunal tissue compared with other tissues analyzed. Resin acid concentration in blood was only one-tenth of that measured in intestinal tissue, indicating that liver, and other tissues rapidly remove these compounds from the plasma. Compounds taken up from the intestine enter the portal vein and finally the liver. One of the most important functions of the liver is to render xenobiotic and/or toxic lipophilic compounds harmless and in more water-soluble form. This can be achieved by many different reaction types, such as oxidation, reduction, hydrolysis, or conjugation (glucuronidation and sulfation), the ultimate objective being to facilitate their elimination from the body $(18,19)$. In the broiler chickens in this trial, the liver appeared to process and pass resin acids to hepatic ducts rapidly, as their residual concentration in liver tissue was low and all resin acids were in conjugated form. The highest concentration of resin acids was measured in bile, of which about $80 \%$ was in conjugated form. The fact that also a substantial amount of free resin acids was found in bile suggests that some of these acids were directed to the bile duct unprocessed. The rate of resin acid uptake to hepatic cells possibly exceeded the rate of their processing, leading to resin acid bypass and/or incomplete conjugation. In enterohepatic circulation, the common bile duct leads to the duodenum, and resin acids, together with their conjugates and metabolites, can re-enter the intestinal tract. In the jejunum, distal to the duodenum where bile is secreted, the proportion of total resin acids recovered was at most $70 \%$ of ingested in-feed resin acids and, of those, about $65 \%$ were in conjugated form. This means that no more than $25 \%$ of resin acids in the jejunum could have come directly from the ingested feed, with no prior absorption and enterohepatic circulation through the liver.

It is well-known that intestinal bacteria are capable of hydrolyzing glucuronide and sulfate conjugates, thus potentially enabling re-absorption of drugs from the intestine (20-22). In the present study, the degree of conjugation of resin acids in the jejunum and ileum was the same, indicating that bacteria of the small intestine did not hydrolyze the conjugates to any measurable extent. However, in excreta resin acids were mainly in free form, suggesting that bacteria in the cecum and large intestine actively deconjugated resin acid conjugates. Many aerobic and anaerobic bacteria are not only able to deconjugate, but also to convert resin acids to other compounds (23). According to the results of the present study, the total yield of resin acids did not decrease on moving from ileum to excreta. This suggests that bacteria in the lower intestine of the broiler chickens did not degrade resin acids. Interestingly, a smaller proportion of dehydroabietic acid than abietic acid was in conjugated form in digesta and feces. In bile, no such difference was detected, and therefore there would not appear to be any difference in the rate of resin acid conjugation in the liver. The numerical difference in the degree of conjugation between abietic acid and dehydroabietic acid increased on moving onward in the intestinal tract. This suggests that the apparent difference 
between the two acids was caused either by a higher rate of deconjugation of dehydroabietic acid by bacteria, or a higher rate of uptake of free abietic acid by the host. Both ways lead to a lower degree of dehydroabietic acid conjugation.

Although the trial conducted was not a toxicity study, it is relevant to review some toxicity studies conducted with resin acids to give a perspective to product doses used in the present study. There are no published toxicity studies for resin acids in broiler chickens. In a 28 -day study on mice, $250 \mathrm{mg}$ of abietic $\mathrm{acid} / \mathrm{kg}$ body weight/day caused no symptoms of intoxication (14). Similar results were obtained in a 15-week study on rats fed $100 \mathrm{mg} / \mathrm{kg}$ body weight/day abietic acid (14). Feeding dehydroabietic acid at $25 \mathrm{mg} / \mathrm{kg}$ body weight/day also had no adverse effects in rats. In the present study, 21-day-old male Ross 308 broiler chickens were close to $1 \mathrm{~kg}$ in weight and with daily feed intake of slightly over 100 grams. Accordingly, the daily intake of total resin acids in birds fed the diet with 3,000 g/t TOFA would be $<30 \mathrm{mg} / \mathrm{kg}$ body weight. Our results are consistent with those in rodent studies, as the TOFA supplement had no adverse effects on performance. In rodents, $\mathrm{LD}_{50}$ values have been determined for abietic acid and dehydroabietic acid, and are reported to be between 2,000 and 4,000 $\mathrm{mg} / \mathrm{kg}$ body weight in all cases, i.e., $\sim 100$-fold higher than the daily intake of resin acids by 21 -day-old broiler chickens in the present study fed 4 -fold the recommended dose of TOFA (14). It can be concluded that resin acids in the TOFA product used in this study are not likely to cause any adverse effects in broiler chickens.

The ultimate question is whether eating broiler chicken meat produced using a TOFA-supplemented diet poses any risk to human end-consumers. In our analysis of edible tissues such as breast meat and liver, the concentration of resin acids was low even when the diet contained 4-fold the recommended

\section{REFERENCES}

1. Logan RL. Tall oil fatty acids. J Am Oil Chem' Soc. (1979) 56:777A-9A. doi: $10.1007 / \mathrm{BF} 02667443$

2. Kettunen H, Vuorenmaa J, Rinttilä T, Grönberg H, Valkonen E, Apajalahti J. Natural resin acid-enriched composition as modulator of intestinal microbiota and performance enhancer in broiler chicken. J Appl Anim Nutr. (2015) 3:e2. doi: 10.1017/jan.2014.11

3. Kettunen H, van Eerden E, Lipinski K, Rinttilä T, Valkonen E, Vuorenmaa J. Dietary resin acid composition as a performance enhancer for broiler chickens. J Appl Anim Nutr. (2017) 5:e3. doi: 10.1017/jan. 2016.10

4. Vienola K, Jurgens G, Vuorenmaa J, Apajalahti J. Tall oil fatty acid inclusion in the diet improves performance and increases ileal density of lactobacilli in broiler chickens. Br Poult Sci. (2018) 59:349-55. doi: 10.1080/00071668.2018.1455965

5. Aguirre M, Vuorenmaa J, Valkonen E, Kettunen H, Callens C, Haesebrouck $\mathrm{F}$, et al. In-feed resin acids reduce matrix metalloproteinase activity in the ileal mucosa of healthy broilers without inducing major effects on the gut microbiota. Vet Res. (2019) 50:15. doi: 10.1186/s13567-019-0633-3

6. Kettunen H, Vuorenmaa J, Vienola K, Valkonen E, Apajalahti J, Vartiainen $\mathrm{S}$. Resin acid composition reduces small-intestinal expression of collagendegrading matrix metalloproteinases in broilers. In: Proceedings of the 6th International Conference on Poultry Intestinal Health. Rome (2019).

7. Vuorenmaa J, Valkonen E, Apajalahti J, Kettunen H, Vienola K. Beneficial performance effect of tall oil fatty acids is likely based on the effects of resin dose of TOFA. Breast meat contained $25 \mu \mathrm{g} / \mathrm{kg}$ of abietic and dehydroabietic acids, in fat tissue resin acids were below detection, and liver contained $<300 \mu \mathrm{g} / \mathrm{kg}$. Thus, in a single meal, a consumer would ingest clearly $<100 \mu \mathrm{g}$ of resin acids, and, at most, only some micrograms $/ \mathrm{kg}$ body weight. It can be concluded that consumers would not be unintentionally exposed to resin acids to a degree that would pose any health risks. However, it would not be surprising if human health products with resin acids are launched in the near future due to their anti-inflammatory effect and other beneficial effects on intestinal health.

\section{DATA AVAILABILITY STATEMENT}

All datasets generated for this study are included in the article/supplementary material.

\section{ETHICS STATEMENT}

Ethical review and approval was not required for the animal study because practices used were not likely to cause pain, suffering, distress or lasting harm equivalent to, or higher than, that caused by the introduction of a needle in accordance with good veterinary practice (EU Directive 2010/63/EU, Chapter I, Article 1, Paragraph 5).

\section{AUTHOR CONTRIBUTIONS}

KV was responsible for the broiler trial and tissue sampling. KR carried out the resin acid analysis. JA drafted the manuscript. All authors contributed to the design of the study, interpretation of results, editing, and scientific discussions. acids. Proceedings of the 22nd European Symposium on Poultry Nutrition. Gdansk (2019).

8. Fritsche KL, Cassity NA, Huang SC. Effect of dietary fats on the fatty acid compositions of serum and immune tissues in chickens. Poult Sci. (1991) 70:1213-22. doi: 10.3382/ps.0701213

9. Willson NL, Forder REA, Tearle RG, Nattrass GS, Hughes RJ, Hynd PI. Evaluation of fatty acid metabolism and innate immunity interactions between commercial broiler, F1 layer $\times$ broiler cross and commercial layer strains selected for different growth potentials. J Anim Sci Biotechnol. (2017) 8:70. doi: 10.1186/s40104-017-0202-4

10. Oikari A, Holmbom B, Bister H. Uptake of resin acids into tissues of trout (Salmo gairdneri Richardson). Ann Zool Fennici. (1982) 19:61-4.

11. Leppänen H, Oikari A. Occurrence of retene and resin acids in sediments and fish bile from a lake receiving pulp and paper mill effluents. Environ Toxicol Chem. (1999) 18:1498-505. doi: 10.1002/etc.5620 180723

12. Villeneuve DC, Yagminas AP, Marino IA, Becking GC. Toxicity studies on dehydroabietic acid. Bull Environ Contam Toxicol. (1977) 18:42-7. doi: 10.1007/BF01686303

13. Domanski JJ. Toxicology. In: Zinkel DF, Russell J, editors. Naval Stores - Production, Chemistry, Utilization. New York, NY: Pulp Chemicals Association (1989). p. 895-941.

14. Abietic acid. In: Hartwig A, editor. The MAK-Collection for Occupational Health and Safety: Part I: MAK Value Documentations 2013. Weinheim: Deutsche Forschungsgemeinschaft; Wiley-VCH Verlag GmbH \& Co (2013). p. 1-31. doi: 10.1002/3527600418.mb51410kske3413 
15. Meriläinen PS, Krasnov A, Oikari A. Time- and concentration-dependent metabolic and genomic responses to exposure to resin acids in brown trout (Salmo trutta m. lacustris). Environ Toxicol Chem. (2007) 26:1827-35. doi: 10.1897/06-521R.1

16. Meriläinen P, Oikari A. Exposure assessment of fishes to a modern pulp and paper mill effluents after a black liquor spill. Environ Monit Assess. (2008) 144:419-35. doi: 10.1007/s10661-007-0004-9

17. Short FJ, Gorton P, Wiseman J, Boorman KN. Determination of titanium dioxide added as an inert marker in chicken digestibility studies. Anim Feed Sci Technol. (1996) 59:215-21. doi: 10.1016/0377-8401(95)0 0916-7

18. Roberts MS, Magnusson BM, Burczynski FJ, Weiss M. Enterohepatic circulation: physiological, pharmacokinetic and clinical implications. Clin Pharmacokinet. (2002) 41:751-90. doi: 10.2165/00003088-20024110000005

19. Akers RM, Denbow DM. Anatomy and Physiology of Domestic Animals. 2nd Ed. Hoboken, NJ: Wiley-Blackwell (2013). p. 483-527.

20. Reddy BS, Weisburger JH, Wynder EL. Fecal bacterial beta-glucuronidase: control by diet. Science. (1974) 183:416-7. doi: 10.1126/science.183.41 23.416

21. Jamwal R, Goswami SK. Gut microbiota and its role in drug metabolism of common drugs - a short review. PTB Reports. (2015) 1:98-103. doi: 10.5530/PTB.1.3.2
22. Pellock SJ, Redinbo MR. Glucuronides in the gut: sugar-driven symbioses between microbe and host. J Biol Chem. (2017) 292:8569-76. doi: 10.1074/jbc.R116.767434

23. Martin V, Yu Z, Mohn W. Recent advances in understanding resin acid biodegradation: microbial diversity and metabolism. Arch Microbiol. (1999) 172:131-8. doi: 10.1007/s002030050752

Conflict of Interest: JA, KV, and KR are employed by an independent commercial contract research company Alimetrics Ltd, and HK and JV by a commercial company Hankkija Ltd whose product was used in the present study.

This project was also jointly funded by Alimetrics and Hankkija. The funders had the following involvement with the study: Hankkija was interested in knowing the mechanism of action of resin acids in broiler chickens and Alimetrics was interested and had the capability to carry out such research.

Copyright (c) 2020 Apajalahti, Vienola, Raatikainen, Kettunen and Vuorenmaa. This is an open-access article distributed under the terms of the Creative Commons Attribution License (CC BY). The use, distribution or reproduction in other forums is permitted, provided the original author(s) and the copyright owner(s) are credited and that the original publication in this journal is cited, in accordance with accepted academic practice. No use, distribution or reproduction is permitted which does not comply with these terms. 